\title{
Utopian State, Concept and Need of RamRajya: A literary Study
}

\author{
Neerja A Gupta \\ PhD \& Principal \\ Bhavan's Arts and Commerce College, Khanpur, Ahmedabad, \\ Advisor and Coordinator \\ Study Abroad Program and Diaspora Studies, Gujarat University, Ahmedabad, \\ Global Chair Academic Council, GOPIO, USA \\ Syndicate Member Gujarat University, Ahmedabad \\ drneerjaarun@yahoo.com
}

Rajya is a political cannon and Ram stands for kalyan (a state of welfare). One should wonder how the concept of a welfare state can be well defined through literary writings. The term literary Ramrajya, in that context may seem vague and absurd. Ram-Rajya makes a concept of a utopian state. When Gandhi presented his aspiration of Ram-Rajya, it was a sort of political arrangement leading to social happiness. But, the hypothesis of Ram-Rajya is better propagated in his and others' literary writings than in political ideas. So much so that political revolutionaries and leaders, when turned authors, they too brought the idea of utopian state, away from their own political module. The reason is that culture resides in literature. It has been projected, propagated and applied through writings right since the ancient days. Some writings are to reassert, others to instruct, still others to remind us of those wonders which lie about us every day. And then there are some which haunt by the very fact that their insights, dark and unsettling though they are, have been tested on the pulse and proven true. Oddly enough, there's something in the measure of these lines, something in the dignity with which they state this elemental fact of nature that Literature is a powerful tool to project the larger design. 
Literature not only projects ideal state but also brings forth the realistic backdrop. An uttered word can be deceptive but a written one is open to multilayer meanings hence it's easy to draw the utopian values from literary ideas from the same political identities who have turned authors. Literature projects effectively the deep yearning for ending of suffering and bringing in much desired state of happiness. Literature also argues the different shade of utopia as it shifts from one culture and society to another. It also justifies the variety of welfare state as desired by time and place.

For the present purpose three such writings have been taken up which have been written by those authors where their political thoughts were equally important. The idea of Ram-Rajya is much more vocal and realistic in their writings than in their political ideology. Gandhi asked for Poorna Swaraj only as a preliminary stage to conceptualized Ram-Rajya. Hind Swaraj was a preliminary attempt to the later call of Poorna Swaraj. This shows that the idea was very much there, which matured after he arrived at the ground zero. His assertion was a happy society which was more accomplished with spiritual wealth. During his visit to Bhopal in 1929, on the on invitation of Prince of Bhopal, Gandhi, while commenting upon his simplicity mentioned in 'Young India':

"I was prepared to find here the same regal splendor, the same wasteful blaze of luxury as one comes across in our other present day Indian State. But to my agreeable surprise I found His Highness living in a "palace" which could be called as such only by courtesy..."YI

The comment was not on simplicity; his admiration is led further by conceptualizing that the simplicity of the living shown by the Prince is a consistent and easy transition to the evolution of Democracy. This further is led to Gandhi's praise for princely states, which he now entertained as hope of democratic Swaraj which he often interpreted as Ramraj. Being conscious of the fact that he is commenting upon Ramraj in a Muslim state he corrects himself by explaining further as what he means by Ramraj:

"I warn my Musalmaan friends against misunderstanding me in my use of the words 'Ramraj'. By Ramraj I don't mean Hindu Raj, I mean by Ramraj Divine raj, the Kingdom of God." YI

Gandhi's assertion of a welfare state is a truly democratic society. His assertion for Utopia is much more than any religion and its principles. The truth and righteousness as to be its pillars. The author Gandhi is projecting Gandhi the politician. The article becomes the preamble to the future Indian system of rule when he further writes: 
"Whether Ram of my imagination ever lived or not on this earth, the ancient ideal of Ramraj is undoubtedly one of true democracy in which the meanest citizen could be sure of swift justice without an elaborate and costly procedure." YI

The other and very different concept of utopia comes from such authors, who aspire for the possibilities of resolution of conflicts in their national and international societies. Apart from the rational, intellectual and political approaches, a major approach has been found through aesthetics when the others proved insufficient. One such attempt of finding reconciliation of Arab-Israeli conflict has been carried out at an international poets meet.

Israel exists in the state of conflict. Apart from physical, the spiritual turmoil is much complicated and grave. It has faced violent dimensions. Women have been living in claustrophobic environment. For Arab-Israeli society the true meaning of utopian state shifts from righteousness and truth to peace. The artistic media plays a proactive role in achieving Peace. In the interesting exhibition recently exhibited at Haifa University, there was a painting: the painting of the Chessmen and the mutilated Chessboard. The well known artist, Samuel Bak, while explaining said: "the Chessmen stands for Rationalism. They speak of the absurdity of war, and the failure of the rational approach to prevent war and poverty" (Ahorani, Songs 17). So to Arab-Israeli society what is much needed is not only peace but also its awareness at ideological, emotional and psychological levels. The horrors of war can be well exposed through literature. Ada Ahorani plays a dynamic role in creating the atmosphere of peace. She writes in 'Metal and Violets in Jerusalem':

In a time of pomegranates

And yellow balloons,

Why are your looks

So bronze-like?

Deep in you

A valve is locked,

And even a warm

Yearning clasp

Cannot unlock

The metallic clasp.

How can I unpuzzle

Your dreams? 
I wish I could sow

Violets under your pores

Until their scent

Melted your metal

Into mine (Ahorani,108)

Ada Ahorani speaks of honey laden decades as teddy bears as exchange for guns. These guns are the terror and the same time they are the weapon of protection, thus less scary and more realistic. Her utopian state is not a gun-less society, but a fully equipped society where each age lives its own worth. Where children don't die before turning into youth. A society which is more civilized. A state free from studs, guns and stones. She challenges both the oppressors and the rulers in 'Teddy Bears for Guns':

My man of the year

Is the wonderful, wise one

Who sat himself in the midst

Of the West with a huge box

Of chubby Teddy Bears

On New Year's Day,

Attracting an endless

Queue of cheering kids -

Holding guns

He playfully showed

With a smile and a wink

And a Teddy Bear hug -

It could be the beginning

Of a honey-laden decade

In a brave new world

By wisely, joyfully trading

(Guns For Teddy Bears)

Her most alarming suggestion comes in the poem 'Bridge of Peace' which starts with:

"They shall sit every man under his vine and under his fig tree, and none shall make them afraid" (Bible, Micah 4.4)' and "He who walks in peace, walk with him." (Koran, Sura 48)'. 
Her direct address to the Arab society gives a call for peace thou artistic media:

My Arab sister, daughter of Abraham,

Let us build a sturdy bridge

From my orange world to yours,

Above the boiling pain of acid rain -

And hold human hands high

Full of free stars of twinkling peace. (Ahorani, 16)

The freedom given in a welfare state and the basic demands of equality are not only well worded but also express strong connotations:

I do not want to be your oppressor

You do not want to be my oppressor,

Or your jailer, or my jailer,

We do not want to make each other afraid (Ahorani, 16)

Her suggestions don't come abruptly, rather they pose the solutions. The image of a peaceful society invites action. Her use of motherly symbols brings peace to a feminine state. The poem ends at a universal note:

Under our vines and under our fig trees

Blossoming on a silvered horizon

Above the bruising and the bleeding

Of poisoned gases and scuds.

So, my Arab sister, let's build a strong

Bridge of jasmine understanding

Where each shall sit with her baby

Under her vine and under her fig tree -

And none shall make them afraid.

And none shall make them afraid! (Ahorani, 16)

The third author taken for the present study is the past Prime Minister of India, Atal Bihari Vajpayee. Troubled with a difficult neighbor he felt while ruling that the country has suffered pains of disturbed state. Negativity from neighbors and fanatic rigidness within the country has led the poet inside to talk about that long shadow of tree which itself burns out in hot sun. His literary projections are less idealistic and 
more obligatory. He wrote in the language which his political position didn't allow him to speak in public. His conception of Ramraj is an all inclusive state which has a rightful existence above party line. He talks of hierarchy with a sense of history:

There are ten or twenty men in each person

Check many times, whomsoever you check. (81)

He has varied concept of good governance starting from Rajdharma. His sense of history and Ramraj mingles in one of his famous writings:

यही आग सरयू के तट पर दशरथ जी के राजमहल में

घन समूह में हल चपला सी प्रकट हुई प्रज्ज्वलति हुई थी

शकति मन-मन, त्रसति वपिर, आकुल मुनविरगण

बोल रही अधर्म की तूती , दुस्तर हुआ धर्म का पालन

तब देश की रक्षार्थ देश का सोया क्षत्रत्वि जागा था

रामरूप में प्रकट हुई यह ज्वालाजसिने असुर जलाये, देश बचाया (162)

(There was a rising once due to the misappropriation of system in king Dasharatha's kingdom. Unethical environment prevailed. Then came Rama, epitome of protection, who not only saved the land from evil spirits but also established ideal system.)

His concept of ideal rule is by giving:

We are such trees which give shelter to other

And stand in the sunny sun with a longing for a little shelter. (63)

He prolongs the argument inner freedom and dignity to all:

सत्य का संघर्ष सत्ता से, न्याय से लड़ता नरिकुशता से, अँधेरे ने दी चुनौती है, करिण अंतमि अस्त होती है....

दांव पर सब कुछ लगा है, रुक नहीं सकते,

टूट सकते हैं, मगर हम झुक नहीं सकते (164)

(Truth is in perpetual war with might. Anarchy prevails. In the dark hours one has to sacrifice everything to correct the system. One may die but can't be stopped by force.) Vajpayee never used poetry as an artistic expression only. His symbols stand for a system that he wished to bring into the society. His warnings are clear and reveal the bruised state of affairs of his contemporary times. 
राजपथ पर भीड़, जनपथ पड़ा सूना

पलटनो का मार्च , होता शोर दूना

शोर में डूबा हुआ स्वाधीनता का स्वर

रुध्ह्र वाणी, लेखनी जड़, कसमसाता उर. (165)

(The Kings celebrate while the common people suffer. Rulers rule by force and try to subdue the right to freedom. No one is allowed to speak freely, there are restrictions on pen and the hearts are suffocated.)

Only love for one's culture, peace and neighbor can attain and preserve good for all. Whether harsh or mild, the words can bring in the ultimate effect that no policy or leader or call can bring in:

Koran or Bible or a martyr's soul,

A church or a temple or a kaaba stone,

All these and more my heart can bear,

Since my religion is love alone. (152)

As the theory of liberation, equity and sameness, the center argument of Ram-Rajya is visualized through literature with the backdrop of mysticism. The present paper shall discuss the issues of equality with relation to the literature written by social reformer turned politician Mahatma Gandhi, a politician turned poet Atal Bihari Vajpayee and a bio-political poet Ada Ahorani.

\section{References}

Ahorani, Ada. ed. 1993. A Song to Life and to World Peace. Jerusalem: Posner and Sons. Ahorani, Ada. 1994, 1997. From the Nile to the Jordan. Tel Aviv, Israel: Eked.

Ahorani, Ada. 2002. Women: Creating A World Beyond War. Haifa: M. Lachman.

Ahorani, Ada. 19-9-1929. Peace Flower: A Space Adventure. Haifa: M. Lachman. 1994, 1996 Gandhi M. K.: YI, p. 305.

Prabhu, R. K. \& Rao U.R. ed. 1960. The Mind of Mahatma Gandhi. Ahemadabad: Navajivan Mudranalaya.

Vajpayee,AtalBihari:1998. Meriikyavanakavitaem. Evam Samskarana. Nayi Dilli: Kitaba Ghara. 